\title{
Çocuklarda patolojik kırıklar
}

\author{
Pathologic fractures in children
}

\author{
Cengiz Yıldırım, Fazlı Levent Umur
}

Sağlık Bilimleri Üniversitesi, Sultan Abdülhamid Han Eğitim ve Araştırma Hastanesi, Ortopedi ve Travmatoloji Servisi, İstanbul

\begin{abstract}
Çocuklarda görülen patolojik kırıklar, tümör, metabolik hastalıklar ve enfeksiyon gibi çeşitli durumlarda görülebilmektedir. Bu durumlardan en sık, benign ya da malign tümörler sonucu oluşan patolojik kırıklarla karşılaşmaktayız. Benign ve malign kemik tümörleri sonucu oluşan patolojik kırıklar erken tanınmalı ve ortopedik cerrah tarafından uygun şekilde tedavi edilmelidir. Çocuklarda patolojik kırığa neden olan en sık benign tümörler basit (unikameral) kemik kistleri, anevrizmal kemik kistleri, non-ossifiye fibroma ve fibröz displazidir. Primer malign kemik tümörleri nadiren patolojik kırığa neden olsa da, daha iyi sonuç alabilmek için bu tümörlerin de bir an önce tanınması gerekmektedir. Ayrıntılı bir öykü, fizik muayene ve radyolojik tetkik; nedeni ortaya koymak ve doğru tedaviye yönlendirmek için gereklidir. Benign lezyonların çoğunda kırık kaynamasında problem olmamaktadır ve lezyon kırık oluştuğu zaman ya da kırık iyileştikten sonra tedavi edilebilir. Malignitesi olan pediatrik hastaların tedavisinde multidisipliner yaklaşım gereklidir. Patolojik kırıklar ampütasyon ile tedavi edilmemelidir; bu kırıklar iyileşebilir ve endike olan durumlarda ekstremite kurtarma cerrahisi yapılabilir. Bu yazımızda, diğer durumlara göre daha sık karşılaştığımız benign ve malign kemik tümörleri zemininde çocuklarda görülen patolojik kırıklar konusuna değineceğiz.
\end{abstract}

Anahtar sözcülkler: patolojik kırı; benign; malign; kemik tümörü; çocuklar
Pathologic fractures in children can occur due to a variety of conditions, ranging from tumors and metabolic diseases to infection. We encounter pathologic fractures in children mostly due to benign or malign bone tumors among the above-mentioned conditions. Pathologic fractures as a reason of benign and malignant bone tumors should be recognised early and managed appropriately by the orthopaedic surgeon. The most common benign bone tumors that cause pathologic fractures in children are unicameral bone cysts, aneurysmal bone cysts, non-ossifying fibromas and fibrous dysplasia. Although a primary bone malignancy causes pathologic fractures rarely, these should be also recognised early in order to achieve better outcomes. A thorough history, physical and radiological examination are crucial to determine the cause and guide the appropriate treatment. In the majority of benign lesions the fracture will heal and the lesion can be addressed at the time of the fracture, or after the fracture is healed. A multidisciplinary approach is necessary in caring for pediatric patients with malignancies. Pathologic fractures should not be treated by amputation; these fractures can heal and limb salvage can be performed when indicated. In this paper, we aim to review the pathologic fractures in children related mostly to benign and malign bone tumors.

Key words: pathologic fracture; benign; malign; bone tumor; children

Çocuklarda kemik plastisitesi yetişkinlere göre daha yüksek olduğundan, patolojik kırık oluşumu için mineral yoğunluğu ve mikro mimari yapıda daha fazla kayıp olması gereklidir. Pediatrik hasta popülasyonunda minimal travma ile oluşmuş kırıklarda, alışılagelenin dışındaki kırık lokalizasyonları ve direkt grafilerde anormal kemik yapısı görüldüğü durumlarda, patolojik kırıktan şüphelenilmesi gerekir. Şüphelenilen hastalarda ayrıntılı bir anamnez ve fizik muayene tanıda yardımcı olabilir. Direkt grafiler genellikle ilk tercih edilen tetkiktir ve

- Illetişim adresi: Doç. Dr. Cengiz Yıldırım, Sağlık Bilimleri Üniversitesi, Sultan Abdülhamid Han Eğitim ve Araştırma Hastanesi, Ortopedi ve Travmatoloji Servisi Tıbbiye Caddesi, Üsküdar, İstanbul Tel: 0533 - 4286846 e-posta: drcengizyildirim@yahoo.com

- Geliş tarihi: 2 Şubat $2019 \quad$ Kabul tarihi: 2 Şubat 2019 
sayı, boyut, lokalizasyon, içerik, büyüme modeli ve periost reaksiyonunun tanımlanmasında yardımcı olur. ${ }^{[3]}$

Patolojik kırıklar genellikle ağrı ve deformite ile seyreden mikro- ve makro-kırıklar olarak karşımıza çıkar. Mikro-kırıklar çoğunlukla metafizer bölgelerdeki trabeküler kemiklerde ve vertebra korpuslarında görülür ve tipik olarak non-deplasedir. ${ }^{[1]}$ Bu nedenle birçoğu tanı almaz. Tekrarlayıcı mikro-kırıklar fibröz displazide proksimal femurda görülen "çoban asası" deformitesi gibi deformitelere neden olabilir.

Çocukluk çağı patolojik kırıklarının çoğu benign kemik tümörü, tümör benzeri oluşumlar, metabolik hastalıklar ve enfeksiyon sonucunda oluşur. Patolojik kırıklı hastaların değerlendirilmesinde ayrıntılı anamnez ve fizik muayene tanıya ulaşmada hayati öneme sahiptir.

Ayırıcı tanı çok sayıda olasılık içermekle birlikte, hastanın yaşı ayırıcı tanıların daraltılmasında yararlı bir bilgidir (Tablo 1). illeri görüntüleme yöntemleri (bilgisayarlı tomografi $[\mathrm{BT}]$, manyetik rezonans [MR] görüntüleme, sintigrafi), her olguda gerekli olmamakla birlikte, lezyonun tanısında ve yayılımının belirlenerek cerrahi öncesi planlamada yararlı olabilir. Çoğu olgu tanısal amaçlı veya tanısal ve tedavi planlaması amacıyla biyopsi gerektirir. Radyolojik incelemelerde malignite bulgusu gösteren lezyonlarda biyopsi geç kalınmadan uygulanmalı, ancak tüm tümöral lezyonlarda biyopsinin tanının son, tedavinin ilk basamağı olduğu prensibine bağlı kalınarak gerekli tüm görüntülemeler biyopsi öncesinde tamamlanmalıdır. Biyopsi lokalizasyonu ve şekli ile birlikte uygulanması tercihen nihai tedaviyi uygulayacak merkezce yapılmalıdır. ${ }^{[4]}$

\section{BASIT (UNIKAMERAL) KEMIK KISTI (UKK)}

Basit (unikameral) kemik kistleri benign, berrak sıvı içeren, epifiz komşuluğunda genellikle eksentrik yerleşimli lezyonlardır. Hastaların \%85’i 20 yaş altındadır. En sık proksimal femur ve proksimal humerus yerleşimlidir. ${ }^{[1]}$ Hastaların \%75'inde patolojik kırık görülür. Radyolojik olarak belirgin sınırlı, ekspansil, kortekste incelmeye neden olan lezyonlardır. Direkt grafi, BT ve MR görüntülemelerinde kist duvarının bir bölümünün kırılarak kavite içine düşmesi ile oluşan patognomonik "düşen yaprak" görüntüsü izlenebilir (Şekil 1). [ ${ }^{[]}$UKK'nin doğal seyri, kist boyutlarının büyümesinde durma ile normal kemik yapımının devamı sonucu giderek epifizden uzaklaşma göstermesidir. Bir kısmında spontan iyileşme görülmekle birlikte çoğunluğu adolesan dönemden sonra inaktif, latent duruma geçerek kalır. UKK'ye bağlı patolojik kırıklarda tedavi prensibi, önce kırığı, sonrasında lezyonu tedavi etmek şeklindedir. Kırık tedavisinde, yük taşımayan bölgelerde, stabil kırıklarda konservatif tedavi metodları tercih edilir; yük taşıyan bölgelerde ve instabil kırıklarda hem kırık stabilizasyonu hem de lezyonun tedavisinin yapıldığı cerrahi planlamalar tercih edilmelidir. Kırık sonrası proksimal femur

Tablo 1. Yaş dağılımına göre patolojik kırık predispozan lezyonlar ${ }^{[1]}$

\begin{tabular}{|c|c|c|}
\hline Yaş & Benign Lezyonlar & Malign Lezyonlar \\
\hline$<5$ & $\begin{array}{l}\text { - Osteomiyelit } \\
\text { - Eozinofilik granülom } \\
\text { - Hand-Schuller-Christian hastalığı }\end{array}$ & $\begin{array}{l}\text { - Metastatik (Nöroblastom, Wilm's tümörü) } \\
\text { - Lösemi } \\
\text { - Ewing sarkom } \\
\text { - Fibrosarkom } \\
\text { - Eozinofilik Granülom/Letterer-Siwe hastalı̆̆ı }\end{array}$ \\
\hline $5-10$ & $\begin{array}{l}\text { - Unikameral Kemik Kisti (UKK) } \\
\text { - Anevrizmal Kemik Kisti (AKK) } \\
\text { - Nonossifiye Fibrom (NOF) } \\
\text { - Osteokondrom } \\
\text { - Fibröz Displazi (FD) } \\
\text { - Enkondrom/Ollier hastalığı } \\
\text { - Nörofibromatozis/Konjenital tibia psödoartrozu }\end{array}$ & $\begin{array}{l}\text { - Lösemi } \\
\text { - Osteosarkom } \\
\text { - Ewing Sarkom }\end{array}$ \\
\hline $10-20$ & $\begin{array}{l}\text { - UKK } \\
\text { - } \text { AKK } \\
\text { - NOF } \\
\text { - Osteokondrom } \\
\text { - FD } \\
\text { - Kondroblastom } \\
\text { - Dev hücreli tümör } \\
\text { - Osteoid osteoma }\end{array}$ & $\begin{array}{l}\text { - Lösemi } \\
\text { - Lenfoma } \\
\text { - Osteosarkom } \\
\text { - Ewing sarkom }\end{array}$ \\
\hline
\end{tabular}


yerleşimli kistler proksimal humerus yerleşimli olanlara göre daha yüksek iyileşme şansına sahiptir. Ancak, proksimal femur yerleşimli kistler varus deformitesi ve hatta avasküler nekroz gibi komplikasyon olasılıklarına sahiptir. Tedavinin amacı kist oluşumunu ortadan kaldırmak ve ileride oluşabilecek kırık ve deformiteleri önlemektir. Tedavide dekompresyon, kist duvarının tahrip edilmesi, enjeksiyon (steroid, kemik iliği aspiratı, DBM (demineralize kemik matriksi), kalsiyum sülfat, allogreft) yöntemleri ile yük taşıyan bölgelerde tespit teknik kombinasyonları kullanılmaktadır (Şekil 2). ${ }^{[6]}$

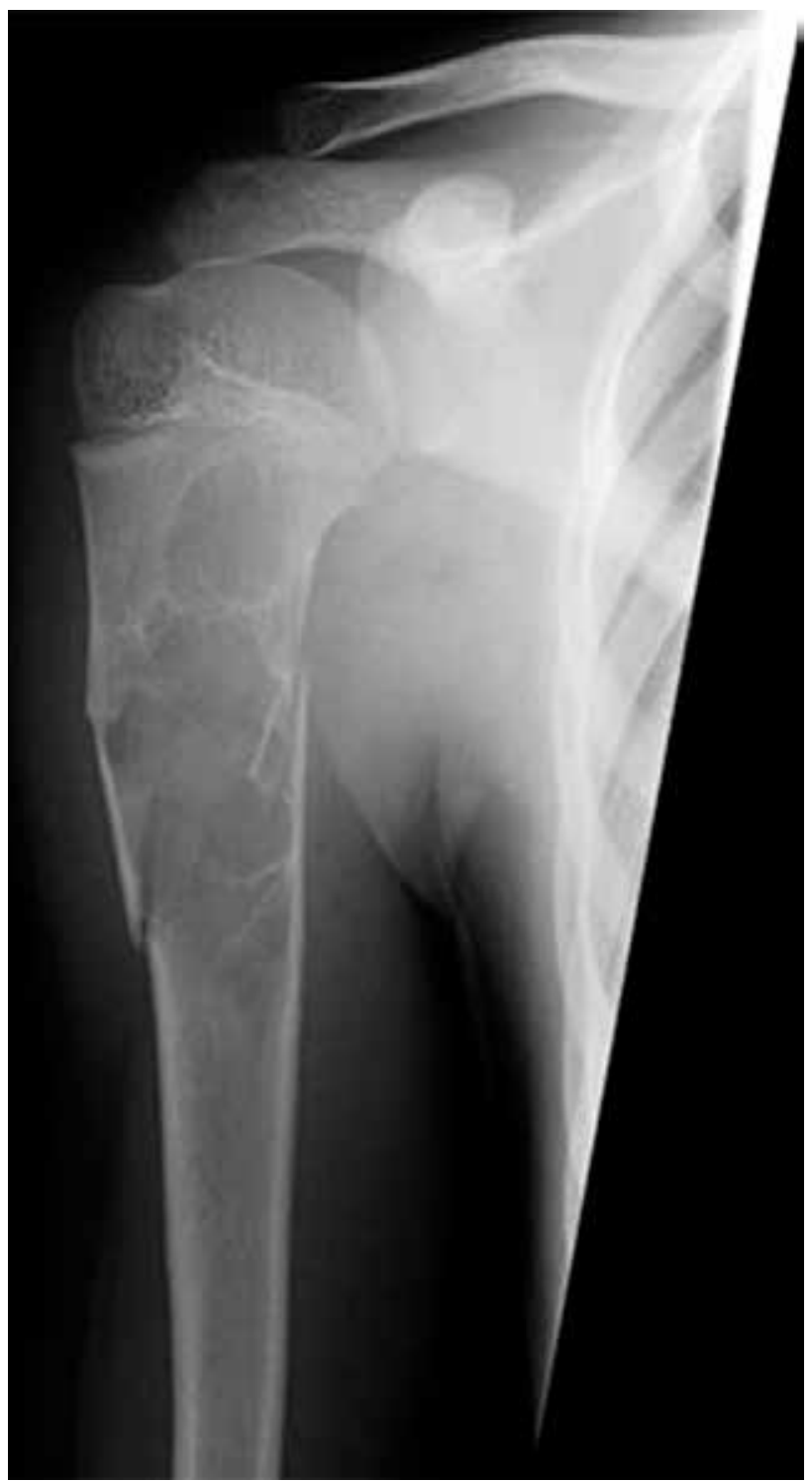

Şekil 1. Proksimal humerus yerleşimli UKK zemininde humerus proksimalinde oluşan patolojik kırık ve patognomonik "düşen yaprak" bulgusu.

\section{NON-OSSIFIYE FIBROM (NOF)}

Çocukluk çağının en sık görülen benign kemik lezyonudur. Yapılan çalışmalarda, çoğu asemptomatik olmak üzere 20 yaş altı popülasyonda \%30-40 sıklığa sahiptir. ${ }^{[7]}$ Patolojik kırık riski açısından düşük insidansa sahip lezyonlardır. Ancak, alt ekstremitede kemik çapının \%50'sinden fazlasını kaplayan lezyonlarda \%50 oranında kırık riski mevcuttur (Şekil 3). Radyolojik olarak litik, iyi sınırlı, sklerotik kenarlı, lobüle, metafizde eksentrik yerleşimli lezyonlar görülür. Patolojik kırık yoksa periost reaksiyonu izlenmez. Nadiren de olsa daha küçük çaplı lezyonlarda mikrokırık ve stres kırıkları izlenebilir. NOF kaynaklı patolojik kırıkların tedavisi UKK'ler ile benzerlik gösterir. Önce kırık daha sonra gerekliyse lezyonun tedavisi planlanır. Kırık tedavisi sonrası lezyonların çoğunda iyileşme izlenir. Lezyonlar genellikle alt ekstremite yerleşimli olmasına rağmen, tedavide konservatif yöntemler sıklıkla yeterlidir. Yeterli redüksiyon ve immobilizasyon sağlanamayan olgularda lezyonun küretaj sonrası greftlenmesi ile internal tespit yöntemleri uygulanır.

\section{ANEVRIZMAL KEMIK KISTi (AKK)}

Anevrizmal kemik kisti en sık olarak femur, humerus, tibia-fibula ve posterior vertebral bölgelerde görülen, benign, lokal agresif lezyondur. En yüksek prevalansı 12 yaş civarındadır. Olguların 2/3'ü 20 yaş altındadır ve $1 / 3$ 'ünde patolojik kırık görülür. ${ }^{[8]}$

Radyolojik olarak genellikle metafizde, ekspansil, litik, periostu eleve eden, ince bir korteks ile çevrelenmiş, maligniteyi taklit eder şekilde hızlı büyüyen lezyonlar olarak izlenir. İyi sınırlı olabildiği gibi malignite benzeri permeatif bir geçiş zonuna sahip olabilir. MR görüntülerinde tipik olarak multiloküle kaviteler ve sIVI-sıvı seviyeleri izlenir. Ayırıcı tanıda, direkt grafi ve MR görüntüler benzerlik gösterdiği için telenjiektatik osteosarkomdan ayrımı için biyopsi gereklidir.

Lezyonun seyri dört aşamada incelenir: 1) Başlangıç fazı; kemiğin marjinal bölgelerinde osteolizis. 2) Büyüme fazı, kemiğin progresif harabiyetinin görüldüğü dönemdir. 3) Stabilizasyon fazı; tipik AKK radyolojik bulgularının (osseöz septasyonlar içeren ince kemik ile çevrili ekspansil lezyon) görüldüğü dönemdir. 4) İyileşme fazı; bariz progresif kemikleşmenin olduğu bozuk strüktürel yapıya sahip kemik dokunun olduğu dönemdir (Şekil 4). ${ }^{[4]}$ AKK tanısı alan olguların çoğunluğunda cerrahi tedavi uygulandığı için, spontan iyileşme oranları ile ilgili kesin bir veri mevcut değildir.

Lezyon, kırık iyileşmesi ile iyileşmeyeceği için, patolojik kırık ile birlikte tanı sonrası eş zamanlı olarak tedavi edilir. Günümüzde açık küretaj, adjuvan tedavi (yüksek hızlı burr, koterizasyon, etanol, sıvı nitrojen), greftleme 


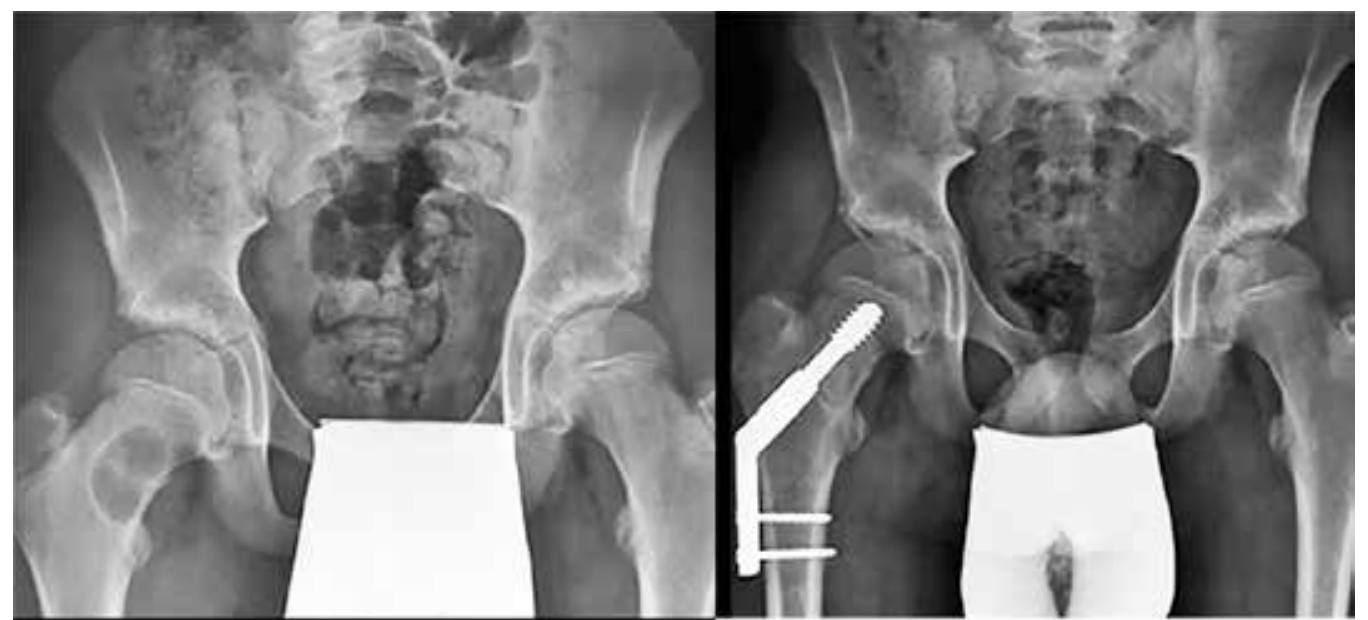

Şekil 2. Femur boyun yerleşimli UKK tedavisi amacıyla yapılan küretaj, greftleme ve internal tespit.

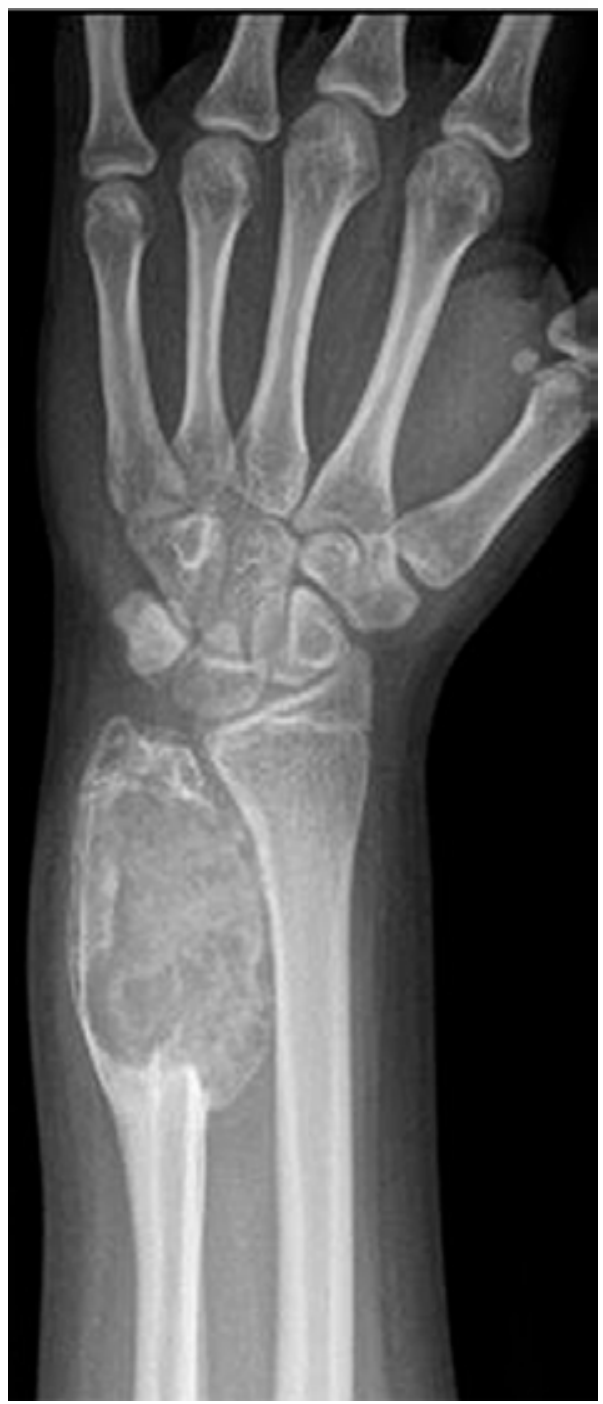

Şekil 3. Patolojik kırığa neden olmuş distal tibia yerleşimli non-ossifiye fibrom.

Şekil 4. Distal ulna yerleşimli anevrizmal kemik kisti. 


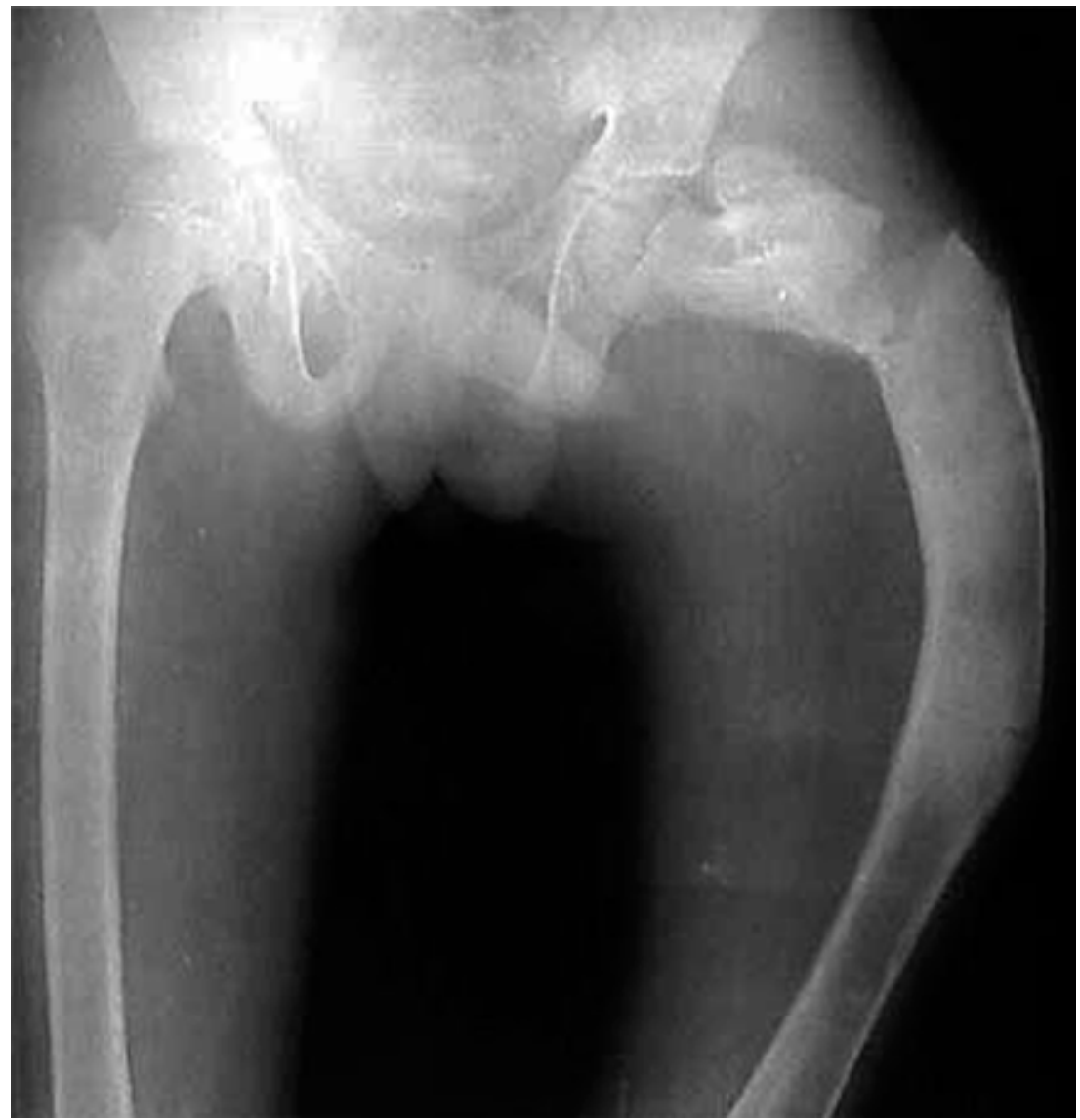

Şekil 5. Femurda fibröz displazi zemininde yıllar içerisinde tekrarlayan kırıklar sonucu oluşan "çoban asası" deformitesi.

ve PMMA (polimetilmetakrilat) yaygın olarak kabul edilen tedavi modaliteleridir. Tüm bu tedavilere rağmen nüks oranları \%20 seviyesinde olabilir. Proksimal femurda mevcut lezyonlar, yüksek nüks oranları ve kırık riski nedeniyle, daha agresif tedavi edilmelidir.

\section{FiBRÖZ DiSPLAZi (FD)}

Fibröz displazi, benign kemik tümörlerinin \%57'sini oluşturan normal kemik dokusunun fibröz dokuya dönüştüğü kalıtımsal olmayan bir lezyondur. Monostotik veya daha nadir olmak üzere polyostotik olabilir. Polyostotik formu McCune-Albright Sendromu (café-au-lait lekeleri, puberte prekoks, fibröz displazi) veya Mazabraud Sendromu (musküler miksoma, fibröz displazi) ile ilgili olabilir. Hemen her yaşta görülebilmekle birlikte, 10 yaş civarında bir insidans artışı mevcuttur. Nadiren de olsa $(\% 0,5)$, tipik olarak tanıdan yaklaşık 15 yıl sonra malign transformasyon görülebilir. ${ }^{[9]}$
Radyolojik olarak; metafiz ya da diyafizde yerleşmiş, coğrafi şekilli, iç kenarlarında belirgin keskin sınırlı, komşu kortekste reaktif kalınlaşmaya neden olan tipik buzlu cam görünümlü lezyonlar izlenir. Polyostotik lezyonlar daha geniş ve coxa vara ya da çoban asası gibi deformitelerle ilişkili olabilir (Şekil 5).

Lezyonlar genellikle lokalize ağrı, şişlik gibi semptomlarla rastlantısal olarak veya patolojik kırıkla tanı alır. Patolojik kırıklar başta proksimal femur olmak üzere \%50 hastada görülür. Proksimal femur dışındaki lezyonlar, patolojik kırıktan ziyade deformite, ekstremite kısalığı, AKK gelişimi gibi olaylarla ilişkilidir. ${ }^{[10]}$

Monostotik lezyonların çoğu, özellikle alt ekstremite dışı lokalizasyonlar ve deformite oluşmamış osseöz yapılarda oluşan kırıklar konservatif olarak tedavi edilebilir. Ancak, lezyon kırık iyileşmesi sonrasında da devam eder. Lezyona yönelik girişim kırık iyileşmesi sonrasına bırakılabilir; ancak bu arada polyostotik lezyon olasılığının ekarte edilmesi için tüm vücut kemik 
taraması önerilir. Polyostotik lezyona sahip hastalar, ilgili sendromların ekarte edilmesi açısından endokrinolojik olarak değerlendirilmelidir. Cerrahi tedavi gereken olgularda biyopsi, küretaj-greftleme ve gerekli ise internal tespit uygulanmalıdır. Proksimal femurdaki lezyonlarda, özellikle deformite mevcutsa, kanüllü vida ile tespit, plak ile osteosentez gibi yöntemlerin, yetersiz tespit, malunion, plak distalinden yeni kırık oluşumu gibi komplikasyonlara açık olduğu unutulmamalıdır. Cerrahi öncesinde ilgili kemiğin bütünü değerlendirilerek lezyonun uzanımından özellikle emin olunmalıdır. Bu olgularda küretaj, kortikal greft kullanımı ve intramedüller tespit yöntemleri özellikle tavsiye edilmektedir.

\section{MALIGN KEMIK TÜMÖRLERI}

Malign primer kemik tümörü zemininde gelişen patolojik kırıklar nadir olarak görülür. Bu oran, osteosarkom hastalarında yaklaşık \%5-15, Ewing sarkomu hastalarında \%10 kadardır. Daha büyük, diyafiz yerleşimli litik, fibroblastik veya telenjiektatik tümörlerde patolojik kırık görülme sıklığı daha yüksektir. Malign tümör zemininde gelişen kırıklarda, kırık tanısı sırasında tümör tanısının atlanması, primer bir kırığa nazaran katastrofik sonuçlara neden olabileceği için dikkatli olunmalıdır.

Direkt grafi ve ilgili tüm kemiği içeren MR incelemeleri; primer tümörün özelliklerinin belirlenmesi, yumuşak doku kitlesi varlığının değerlendirilmesi, nörovasküler yapılara yakınlığın incelenmesi ve skip-metastazların tespiti için hayati öneme haizdir. Tanı, evreleme çalışmaları ve tedavinin ilk aşamalarında kırığa yönelik immobilizasyon, kırığın tipi ve lezyonun yerine göre alçı tespiti, iskelet traksiyonu veya eksternal tespit yöntemleri ile sağlanabilir. Ancak, iskelet traksiyonu ve eksternal tespit uygulamaları sırasında tümörün yayılımının engellenmesi için, pin yerleşimine özel dikkat gösterilmelidir.

Malign kemik tümörlerinin tedavisi kemoterapi, radyoterapi ve cerrahi yöntemlerin kombinasyonunu içerir. Malign tümör zemininde gelişen patolojik kırıkların cerrahi öncesi tedavi safhalarında kaynayabildiği gösterilmiştir. Özellikle pediatrik popülasyonda, malign kemik tümörleri tedavisinde ekstremite koruyucu yaklaşımlar kullanılmakla birlikte, yeterli temiz cerrahi sınır sağlanamayan veya rezidüel ekstremitenin nonfonksiyonel olduğu durumlarda ampütasyon hala bir tedavi seçeneğidir. Radyoterapi içeren tedavi protokolleri sonrasında da kemik kalitesindeki düşüş ve iyileşme potansiyelindeki azalmaya bağlı olarak patolojik kırıklar görülebilir. ${ }^{[11]}$

Patolojik kırığın eşlik ettiği primer malign kemik tümörlerinde kırık hematomuna bağlı lokal nüks,

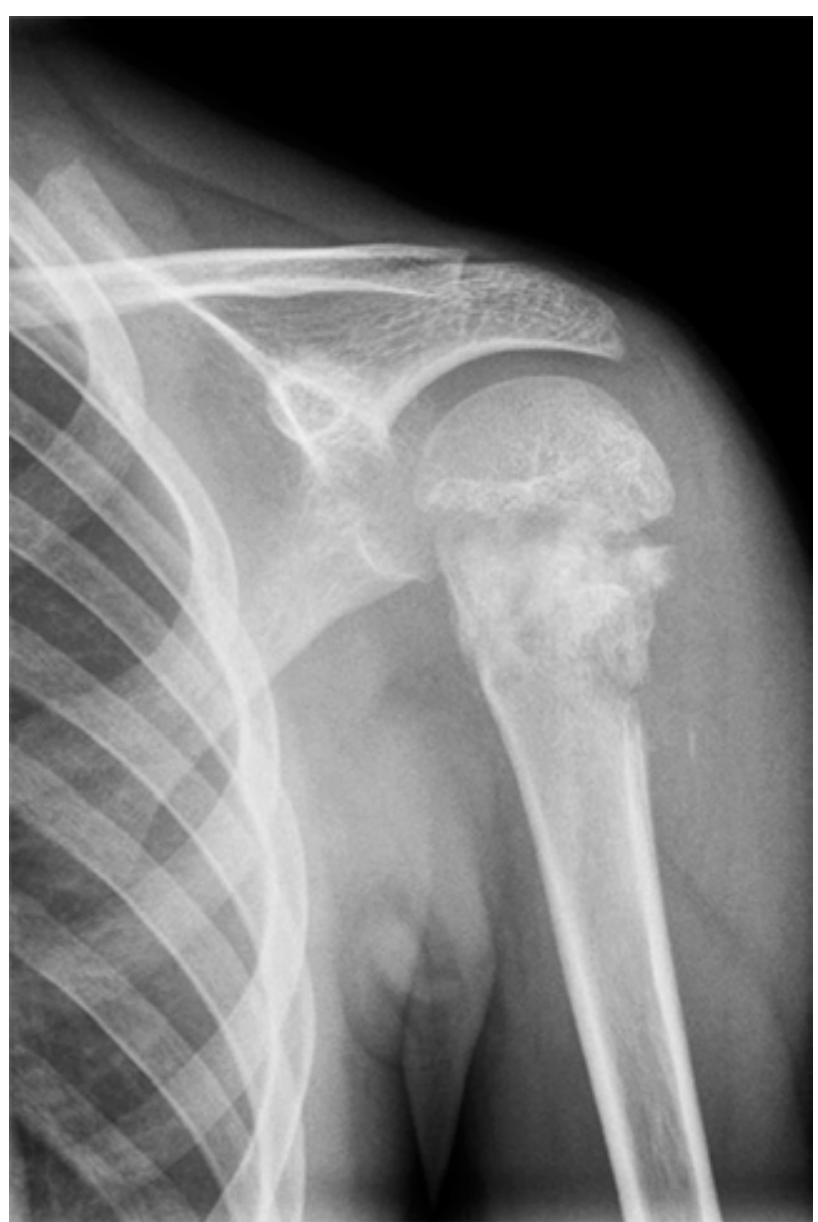

Şekil 6. Proksimal humerusta patolojik kırı̆ga neden olmuş osteosarkom olgusu.

mikro-dolaşımın bozulmasına bağı uzak metastaz riski ile ilgili geçmişte birçok çalışma olmasına rağmen, bu hasta grubunda ekstremite koruyucu cerrahi ile ampütasyon yapılanlar arasında toplam sağkalım ve lokal nüks açısından fark olmadığını gösteren birçok çalışma da mevcuttur. ${ }^{[12]} \mathrm{Bu}$ nedenle, pediatrik popülasyonda patolojik kırığın eşlik ettiği primer malign kemik tümör olgularında ekstremite koruyucu tedavi seçenekleri yaygın olarak tercih edilmektedir (Şekil 6).

\section{KAYNAKLAR}

1. BeatyJH, Kasser JR, editors. Rockwood and Wilkins' Fractures in Children, 6th ed. Philadelphia: Lippincott Williams \& Wilkins; 2011.

2. Dormans JP, Pill SG. Fractures through bone cysts: unicameral bone cysts, aneurysmal bone cysts, fibrous cortical defects, and non-ossifying fibromas. Instr Course Lect 2002;51:457-67. 
3. Snyder BD, Hauser-Kara DA, Hipp JA, Zurakowski D, Hecht AC, Gebhardt MC.. Predicting fracture through benign skeletal lesions with quantitative computed tomography. J Bone Joint Surg Am 2006;88-A(1):55-70. Crossref

4. Peabody TD, Simon MA. Making the diagnosis: keys to a successful biopsy in children with bone and soft-tissue tumors. Orthop Clin North Am 1996;27(3):453-9.

5. De Mattos CBR, Binitie O, Dormans JP. Pathological fractures in children. Bone Joint Res 2012;1(10):272-80. Crossref

6. Tey IK, Mahadev A, Lim KB, Lee EH, Nathan SS. Active unicameral bone cysts in the upper limb are at greater risk of fracture. J Orthop Surg (Hong Kong) 2009;17(2):157-60. Crossref

7. Betsy M, Kupersmith LM, Springfield DS. Metaphyseal fibrous defects. J Am Acad Orthop Surg 2004;12(2):89-95. Crossref

8. Cottalorda J, Kohler R, Sales de Gauzy J, Chotel F, Mazda K, Gérard Lefort, Louahem D, Bourelle S, Dimeglio A. Epidemiology of aneurysmal bone cyst in children: a multicenter study and literature review. J Pediatr Orthop B 2004;13(6):389-94. Crossref
9. Hoshi M, Matsumoto S, Manabe J, Tanizawa T, Shigemitsu T, Izawa N, Kengo T, Kawaguchi N. Malignant change secondary to fibrous dysplasia. Int J Clin Oncol 2006;11(3):229-35. Crossref

10. Ippolito E, Bray EW, Corsi A, Maio FD, Exner UG, Robey PG, Grill F, Lala R, Massobrio M, Pinggera O, Riminucci M, Snela S, Zambakidis C, Bianco P. Natural history and treatment of fibrous dysplasia of bone: a multicenter clinicopathologic study promoted by the European Pediatric Orthopaedic Society. J Pediatr Orthop B 2003;12(3):155-77. Crossref

11. Fuchs B, Valenzuela RG, Sim FH. Pathologic fracture as a complication in the treatment of Ewing's sarcoma. Clin Orthop Relat Res 2003;415:25-30. Crossref

12. Hosalkar HS, Dormans JP. Limb sparing surgery for pediatric musculoskeletal tumors. Pediatr Blood Cancer 2004;42(4):295-310. Crossref 